\title{
Rapid PCR in a continuous flow device
}

\author{
Masahiko Hashimoto, ${ }^{b}$ Pin-Chuan Chen, ${ }^{a}$ Michael W. Mitchell, ${ }^{a}$ Dimitris E. Nikitopoulos ${ }^{a}$ \\ Steven A. Soper ${ }^{b}$ and Michael C. Murphy ${ }^{a}$ \\ a Department of Mechanical Engineering, Louisiana State University, Baton Rouge LA \\ 70803, USA \\ ${ }^{b}$ Department of Chemistry, Louisiana State University, Baton Rouge LA 70803, USA
}

Received 7th May 2004, Accepted 13th August 2004

First published as an Advance Article on the web 19th October 2004

Continuous flow polymerase chain reaction (CFPCR) devices are compact reactors suitable for microfabrication and the rapid amplification of target DNAs. For a given reactor design, the amplification time can be reduced simply by increasing the flow velocity through the isothermal zones of the device; for flow velocities near the design value, the PCR cocktail reaches thermal equilibrium at each zone quickly, so that near ideal temperature profiles can be obtained. However, at high flow velocities there are penalties of an increased pressure drop and a reduced residence time in each temperature zone for the DNA/reagent mixture, that potentially affect amplification efficiency. This study was carried out to evaluate the thermal and biochemical effects of high flow velocities in a spiral, 20 cycle CFPCR device. Finite element analysis (FEA) was used to determine the steady-state temperature distribution along the micro-channel and the temperature of the DNA/reagent mixture in each temperature zone as a function of linear velocity. The critical transition was between the denaturation $\left(95{ }^{\circ} \mathrm{C}\right)$ and renaturation $\left(55^{\circ} \mathrm{C}-68{ }^{\circ} \mathrm{C}\right)$ zones; above $6 \mathrm{~mm} \mathrm{~s}^{-1}$ the fluid in a passively-cooled channel could not be reduced to the desired temperature and the duration of the temperature transition between zones increased with increased velocity. The amplification performance of the CFPCR as a function of linear velocity was assessed using 500 and 997 base pair (bp) fragments from $\lambda$-DNA. Amplifications at velocities ranging from $1 \mathrm{~mm} \mathrm{~s}^{-1}$ to $20 \mathrm{~mm} \mathrm{~s}^{-1}$ were investigated. The $500 \mathrm{bp}$ fragment could be observed in a total reaction time of $1.7 \mathrm{~min}\left(5.2 \mathrm{~s} \mathrm{cycle}^{-1}\right)$ and the $997 \mathrm{bp}$ fragment could be detected in $3.2 \mathrm{~min}(9.7 \mathrm{~s}$ $\mathrm{cycle}^{-1}$ ). The longer amplification time required for detection of the $997 \mathrm{bp}$ fragment was due to the device being operated at its enzyme kinetic limit (i.e., Taq polymerase deoxynucleotide incorporation rate).

\section{Introduction}

The polymerase chain reaction (PCR) is a powerful technique used to exponentially amplify specific DNA sequences of interest through repetitive temperature cycling. ${ }^{1}$ The temperatures that are typically used in PCR include $90{ }^{\circ} \mathrm{C}-94{ }^{\circ} \mathrm{C}$ for denaturation of the double-stranded (ds) DNA molecule, $50{ }^{\circ} \mathrm{C}-70{ }^{\circ} \mathrm{C}$ for renaturation of the primers to the singlestranded (ss) DNA template, and $70{ }^{\circ} \mathrm{C}-75{ }^{\circ} \mathrm{C}$ for enzymatic extension (extension) of the primers. While PCR can produce sufficient quantities of material for detection even at the single copy level, fast reporting of target sequences requires the ability to rapidly thermal cycle the PCR cocktail containing the target sequence. Rapid reporting of PCR results is particularly important in applications such as the detection of air-borne pathogens, including anthrax,,3 and real-time molecular forecasting during sensitive surgical procedures. ${ }^{4,5}$

The speed of thermal cycling is usually instrument limited. For example, some commercial PCR machines are based on a temperature-controlled metal block holding tubes containing the PCR cocktail. Standard protocols for 30 thermal cycles can require $\sim 2 \mathrm{~h}$ of processing time $\left(240 \mathrm{~s} \mathrm{cycle}^{-1}\right)$. A large fraction of that time is needed to heat and cool the cocktail due to the need for bringing the large metal block to the cycle equilibrium temperature and to transfer heat to the cocktail through the microfuge tubes. Therefore, the cycle time is set by the thermal capacitance of the metal block and the heat transfer through the plastic microfuge tubes.

Theoretically, PCR can be carried out much more rapidly if temperature equilibration of the PCR cocktail in the reaction vessel at each cycle could be accelerated. Wittwer et al. have shown that denaturing and renaturation are almost instantaneous (less than $1 \mathrm{~s}$ ). ${ }^{6,7}$ Classical kinetic studies on DNA renaturation also predict rapid annealing, because of the high primer concentration typically used in DNA amplification. ${ }^{8}$ Therefore, PCR cycle times are ultimately limited by the elongation time and thus, the enzyme kinetics, which in turn will depend on the length of the amplified product. Investigators have shown that Taq DNA polymerase has an extension rate of $60-100$ nucleotides $\mathrm{s}^{-1}$ at $72{ }^{\circ} \mathrm{C} .{ }^{8,9}$ It should be theoretically possible to perform $30 \mathrm{PCR}$ cycles in $2.5 \min \left(5 \mathrm{~s} \mathrm{cycle}^{-1} ; 1 \mathrm{~s}: 1 \mathrm{~s}: 3 \mathrm{~s}\right.$, denaturation : renaturation : polymerase extension) for a $300 \mathrm{bp}$ amplicon if there are no transition times to attain thermal equilibrium between each temperature step thermal cycle within the PCR cocktail. However, as elongation times are decreased, product yields are compromised, especially for long PCR products. ${ }^{7}$

Rapid PCR cycling has been reported in systems using small capillary tubes as the reactor vessels due to their low thermal capacitance allowing fast attainment of thermal equilibrium due to effective heat transfer. Swerdlow et al. were able to amplify a $303 \mathrm{bp}$ target from $\mathrm{M} 13 \mathrm{mp} 18$ at a rate of $20 \mathrm{~s}$ cycle ${ }^{-1} .{ }^{10}$ Oda et al. showed that infrared-mediated thermocycling has the potential to achieve cycle times as fast as 17 s. ${ }^{11}$ Friedman and Meldrum executed the PCR with temperature ramping at $44{ }^{\circ} \mathrm{C} \mathrm{s}^{-1}$ (heating) and $15{ }^{\circ} \mathrm{C} \mathrm{s}^{-1}$ (cooling) by resistive heating of a thin film coating on the outside of a reaction capillary. ${ }^{12}$

Recently, attention has focused on developing microfabricated PCR devices, since they offer lower thermal capacitance, require smaller amounts of reagents for the reaction, possess the potential for automation, and can be integrated with subsequent processing steps, such as gel electrophoresis. During the past decade, a number of groups have designed 
chamber-type PCR chips, where a stationary PCR mixture in a confined space is alternately heated and cooled. ${ }^{13-23}$ Giordano et al. obtained $500 \mathrm{bp}$ target fragments from $\lambda$-phage DNA in a glass microchip format with a total time for amplification of about $200 \mathrm{~s}$ for 15 cycles $\left(12 \mathrm{~s} \mathrm{cycle}^{-1}\right) .^{15}$

Alternatively, DNA amplification can be achieved in a microfluidic platform by moving a PCR mixture in a microchannel repetitively through different temperature zones using a continuous-flow (CF) format. ${ }^{24-36}$ The CFPCR approach can be conducted at relatively high speeds since it is not necessary to heat and cool the amplification chamber repeatedly. ${ }^{26}$ Kopp et al. were able to produce a relatively short target fragment $(176 \mathrm{bp})$ in a cycle time of $4.5 \mathrm{~s}$ by starting the PCR with a large number of templates $\left(\sim 10^{8}\right.$ copies of a $1 \mathrm{kbp}$ PCR product) along with nested primer sets. ${ }^{26}$ Obeid et al. developed a microdevice that integrated CFPCR with cycle number selection and achieved a cycling rate of $13 \mathrm{~s} \mathrm{cycle}{ }^{-1} .{ }^{29}$ Recently, a unique spiral micro-channel with 20 loops $(\sim 1.6 \mathrm{~m})$ was hot embossed into polycarbonate (PC) for rapid continuous flow PCR. ${ }^{32-36}$ The feasibility of the system was demonstrated by conducting the reaction with a constant linear flow velocity $\left(2 \mathrm{~mm} \mathrm{~s}^{-1}\right)$, resulting in a successful amplification of a $500 \mathrm{bp}$ fragment with a cycle rate of $16 \mathrm{~s}$ cycle ${ }^{-1} \cdot{ }^{34}$ Numerical simulations of the thermal and microfluidic response of the system were used to predict system performance. ${ }^{35,36}$

Several groups have reported detailed thermal analyses of micro-PCR devices using finite element methods. ${ }^{36-41}$ Lin et al. optimized a conventional glass-Si micro-reaction chamber and compared the FE results to a simple 1-D heating model. ${ }^{37}$ Continuous flow PCR devices made from polycarbonate, ceramic, and Si-glass were modeled in order to establish the uniformity of the constant temperature zones. ${ }^{35,36,38-41}$

The objective of this work was to evaluate the thermofluidic and biochemical performance of a CFPCR device operated at flow velocities greater than $2 \mathrm{~mm} \mathrm{~s}^{-1}\left(<30 \mathrm{~s}^{\text {cycle }}{ }^{-1}\right.$ and for 20 cycles $<13.3 \mathrm{~min}$ for the complete reaction) to determine whether the theoretical biochemical limit to PCR, which is inevitably determined by enzyme kinetics - specifically the rate of deoxynucleotide incorporation by the Taq polymerase, could be approached and to identify which factors control overall performance. As the velocity of the analyte in the micro-channel increases the temperature profile of the PCR cocktail depends more on convection than conduction through the channel wall and fluid. Therefore, the PCR cocktail temperature profile will vary, although the temperature profile of the channel would remain constant during steady-state operation under closed-loop control. It was assumed that the efficiency of the extension reactions would vary with changes in the PCR cocktail temperature distribution, reducing the amount of PCR product. Finite element models of heat transfer to the fluid were developed as a function of flow velocity to characterize the steady state thermal behavior of the CFPCR system. Biochemical performance of the CFPCR was evaluated experimentally for two fragment lengths at a range of flow velocities.

\section{Thermofluidic modeling}

\section{Configuration}

The topographical layout of the CFPCR chip is shown in Fig. 1a. A polycarbonate cover plate (thickness $=0.25 \mathrm{~mm}$ ) was thermally bonded over the micro-channel, embossed in a $0.40 \mathrm{~mm}$ thick substrate, and electrical resistance film heaters mounted above and below the denaturation and extension temperature zones. Air pockets were milled into additional pieces of polycarbonate to provide thermal insulation above and below these zones. The renaturation zone was passively cooled.
The selection of polycarbonate as the device material and the incorporation of the air pockets were used to establish uniform and distinct temperature zones. ${ }^{34,35}$ Air and polycarbonate have very low thermal conductivities, $0.0293-0.0313 \mathrm{~W} \mathrm{~m}^{-1} \mathrm{~K}^{-1}$ and $0.2 \mathrm{~W} \mathrm{~m}^{-1} \mathrm{~K}^{-1}$, respectively, so they were used to maximize the thermal impedance between the micro-channels and the environment. Both also have a low thermal capacitance so that they are less sensitive to disturbances in temperature when operated under the steady-state thermal conditions of normal CFPCR operation. The penalty was a slightly longer heating transient when the device was initially turned on than would occur with a higher thermal conductivity material such as silicon, but the amplification performance was not affected since the device was operated in the steady-state and not thermally cycled during the reaction.

Natural convection was used to remove heat above the renaturation zone. Although the conductivity of the polycarbonate is low, it is still six times higher than that of air in the flanking pockets. Therefore, the polycarbonate worked like a fin to dissipate heat from the micro-channel to the environment.

\section{Assumptions}

Several assumptions were made in developing the finite element model. The CFPCR model consisted of a single, straight, polycarbonate microfluidic channel measuring $50 \mu \mathrm{m}$ by $150 \mu \mathrm{m}$, which represented one loop of the actual device cut in the middle of the renaturation zone and straightened out (see schematics of the model cross-section in Fig. 1b). The ratio of the lengths of the three temperature zones was 1:1:4 (denaturation : renaturation : extension), corresponding to the ratios on the innermost loop of the spiral device. The ratio of the width of the channel to the width of the device was on the order of 1:1000, so the heating surfaces were assumed to be infinitely long along the $z$-axis. The lateral thermal resistance to conduction was much higher than in the vertical direction ( $y$-axis), so the boundaries in the $z$-direction were taken as adiabatic. By modeling the device as a closed loop, which was cut through the $72{ }^{\circ} \mathrm{C}$ zone and straightened out, the thermal boundary condition at each end of the straight channel segment was also adiabatic (in the $x$-direction). Heat transfer across the air pockets was modeled using an equivalent thermal conductivity that combined conduction through the air and a linearized thermal resistance due to radiation. ${ }^{36}$ Constant heat flux elements, which were shown to produce temperature profiles similar to those obtained with volume heat generation elements, were used to represent the electrical heaters, since the operation of the heaters was under steady-state conditions and the temperature in each zone was under independent closed loop PID control.

The working fluid was modeled as water. For modeling the fluid behavior, entrance effects were neglected because of the very low Reynolds number and the flow in the channel was assumed to be fully-developed and laminar. The no-slip condition was imposed at the channel walls. Due to symmetry, only the top half of the device was modeled.

\section{Methods}

Finite element analysis with ANSYS/CFD-FLOTRAN (vers. 5.7, ANSYS, Inc., Canonsburg, PA) was carried out to evaluate the thermofluidic response of the CFPCR device. Model parameters for the simulations are summarized in Table 1.

Two different, predefined 3-D mesh elements, 3-D brick elements for the micro-channel/fluid and 3-D tetrahedral elements for the air pockets and polycarbonate, were used in the ANSYS simulations. Grid sensitivity was evaluated using three different element sizes for each mesh type to ensure that 


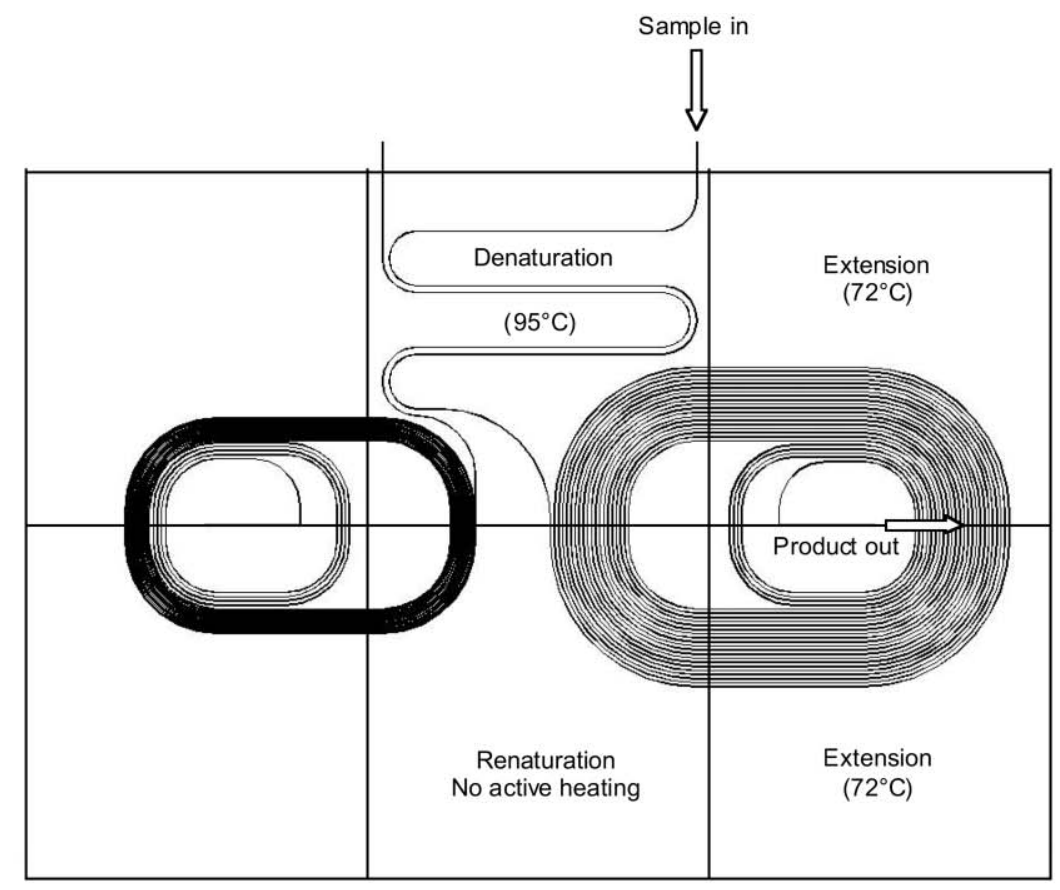

(a)

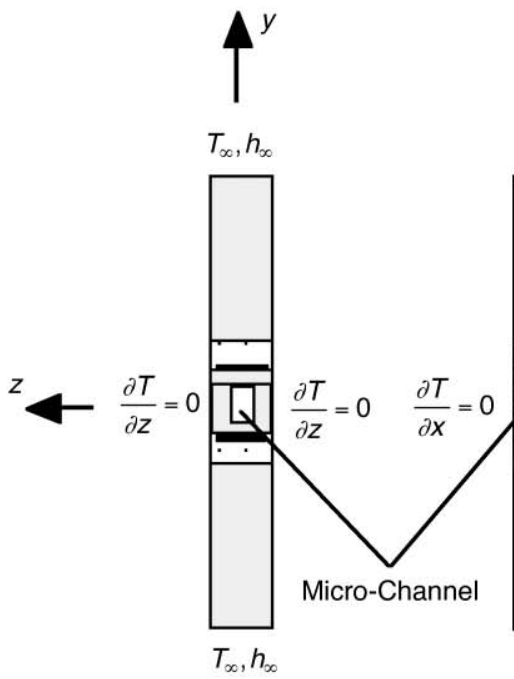

End Cross-Section

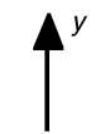

$T_{\infty}, h_{\infty}$

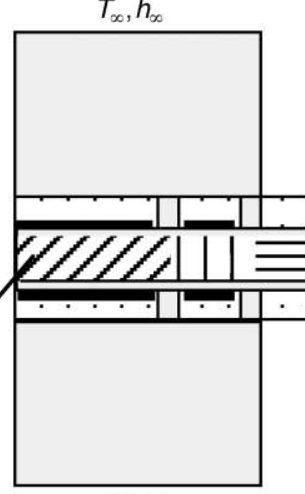

$T_{\infty}, h_{\infty}$

Side Cross-Section

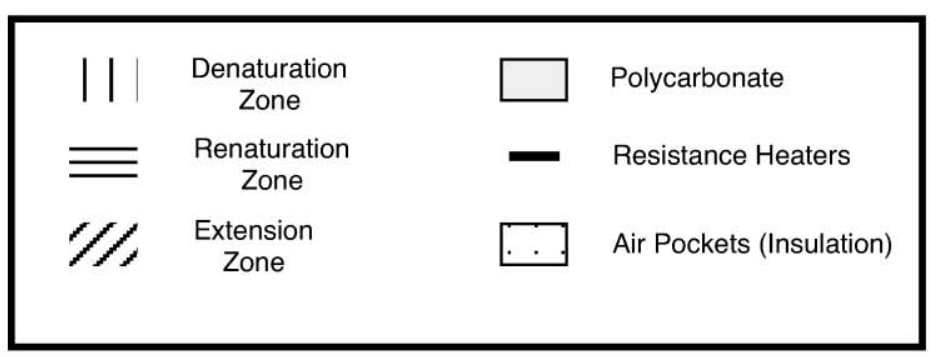

(b)

Fig. 1 Schematic views of the CFPCR device layout and model: (a) Mask layout for CFPCR fabrication. ${ }^{32}$ The device on the right was used in these experiments and had $50 \mu \mathrm{m}$ wide channels separated by $250 \mu \mathrm{m}$. The device on the left had $50 \mu \mathrm{m}$ wide channels separated by $50 \mu \mathrm{m}$ and was not used in this study; (b) End and side views of the single channel model used for finite element analysis of the CFPCR device showing the thermal boundary conditions for the model.

the simulated results were independent of element size. The simulated velocity profiles for the finite element simulations were also compared to the analytical result of Dryden et al. ${ }^{42} \mathrm{~A}$ model that divided the channel into $100 \times 12 \times 12(x-y-z)$ brick elements and used Smart 5 tetrahedral elements for the polycarbonate and air pockets gave the best result when compared to the analytical solution and that combination was used in all further work. 
Table 1 The design parameters and constants used in the FEA simulations

\begin{tabular}{|c|c|c|c|}
\hline Device dimension & Model dimension & Micro-channel dimension & \\
\hline Length/cm & 6 & 6 & \\
\hline 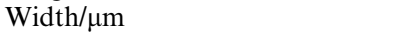 & 150 (wall-channel-wall) & 50 & \\
\hline Height/ $\mu \mathrm{m}$ & 1325 (1/2 channel-cover-air pocket) & 150 & \\
\hline Polycarbonate (Goodfellow, UK) & Thermal conductivity $0.2 \mathrm{~W} \mathrm{~m}^{-1} \mathrm{~K}^{-1}$ & Specific heat $1200 \mathrm{~J} \mathrm{~kg}^{-1} \mathrm{~K}^{-1}$ & Density $1200 \mathrm{~kg} \mathrm{~m}^{-3}$ \\
\hline Fluid properties (water at $74{ }^{\circ} \mathrm{C}$ ) & $\begin{array}{l}\text { Thermal conductivity } 0.668 \mathrm{~W} \mathrm{~m}^{-1} \mathrm{~K}^{-1} \\
\text { Density } 1024 \mathrm{~kg} \mathrm{~m}^{-3}\end{array}$ & $\begin{array}{l}\text { Specific heat } 4191 \mathrm{~J} \mathrm{~kg}^{-1} \mathrm{~K}^{-1} \\
\text { Viscosity } 3.89 \times 10^{-4} \mathrm{~N} \mathrm{~s} \mathrm{~m}^{-2}\end{array}$ & \\
\hline Air properties & $68{ }^{\circ} \mathrm{C}$ & $72{ }^{\circ} \mathrm{C}$ & $95^{\circ} \mathrm{C}$ \\
\hline Conductivity/W m ${ }^{-1} \mathrm{~K}^{-1}$ & 0.0293 & 0.0296 & 0.0313 \\
\hline Specific heat $/ \mathrm{J} \mathrm{kg}^{-1} \mathrm{~K}^{-1}$ & 1008 & 1008 & 1012 \\
\hline Density $/ \mathrm{kg} \mathrm{m}^{-3}$ & 1.017 & 1.0074 & 0.95 \\
\hline
\end{tabular}

Simulations were used to show that the model represented the flow in both the inner and outer spirals of the actual 20 cycle CFPCR device. ${ }^{35,36}$ The residence time ratios in each temperature zone are different for each cycle because the radii of the spirals vary. Based on geometry, the inner spiral was sized so that it would have a denaturation time of $5 \mathrm{~s}$ at a flow velocity of $2 \mathrm{~mm} \mathrm{~s}^{-1}$; simulations showed that the actual time within $\pm 2{ }^{\circ} \mathrm{C}$ of the ideal denaturation temperature was $2.73 \mathrm{~s}$ at that flow velocity. Table 2 compares the cycle times and percentage of the cycle time that the fluid spends in each temperature zone in the two bounding loops. Tolerance bands of $\pm 2{ }^{\circ} \mathrm{C}$ were defined around the setpoint temperatures, so that the temperature zones could be characterized in terms of the residence time in each temperature band and the transition times when the fluid was between the set temperature bands.

\section{Modeling results}

Simulations were run for no flow and eight fluid velocities ranging from $2 \mathrm{~mm} \mathrm{~s}^{-1}$ to $20 \mathrm{~mm} \mathrm{~s}^{-1}$ in order to assess the thermofluidic performance of the CFPCR for high speed conditions. Heat fluxes from the heaters were maintained at the values optimized for the design velocity of $2 \mathrm{~mm} \mathrm{~s}^{-1}$ for all cases. As the flow velocity increased, the residence time of the fluid in the isothermal zones decreased and, consequently, the available time for heat transfer to the fluid was reduced. This modified the boundary conditions for the chemical reactions, potentially affecting the amplification yield of the input DNA.

Fig. 2 shows the variation in thermal performance as a function of fluid velocity. Significant changes in the fluid temperature profile along the channel occurred, particularly for velocities above $6 \mathrm{~mm} \mathrm{~s}^{-1}$. Between 2 and $6 \mathrm{~mm} \mathrm{~s}^{-1}$, the time for the analyte to reach equilibrium within each zone temperature increased, so that the residence time of the fluid at the setpoint temperature was reduced. When the velocity was increased above $10 \mathrm{~mm} \mathrm{~s}^{-1}$, the fluid did not reach the set denaturation temperature of $95{ }^{\circ} \mathrm{C}$; at $20 \mathrm{~mm} \mathrm{~s}^{-1}$ the peak temperature was $5{ }^{\circ} \mathrm{C}$ below the target of $95{ }^{\circ} \mathrm{C}$. As the velocities were increased above $10 \mathrm{~mm} \mathrm{~s}^{-1}$, the target temperature in the extension zone was not reached until the

Table 2 Comparison between the times in each temperature zone and the total cycle time for the inner and outer micro-channels of the spiral CFPCR at a flow velocity of $2 \mathrm{~mm} \mathrm{~s}^{-1}$

\begin{tabular}{|c|c|c|c|c|c|}
\hline & $\begin{array}{l}\text { Length/ } \\
\mathrm{mm}\end{array}$ & $\begin{array}{l}\text { Total } \\
\text { time/s }\end{array}$ & $\begin{array}{l}\text { Ratio of } \\
\text { each temp. } \\
\text { zone }\end{array}$ & $\begin{array}{l}\text { Total } \\
\text { residence } \\
\text { time }(\% \text { cycle })\end{array}$ & $\begin{array}{l}\text { Total } \\
\text { transition } \\
\text { time }(\% \text { cycle })\end{array}$ \\
\hline $\begin{array}{l}\text { Inner } \\
\text { channel }\end{array}$ & 60 & 30 & $1: 1: 4$ & 90 & 10 \\
\hline $\begin{array}{l}\text { Outer } \\
\text { channel }\end{array}$ & 95.82 & 47.91 & $1: 1: 3$ & 91.99 & 7.99 \\
\hline
\end{tabular}

fluid had traveled nearly one quarter of the way into the extension zone.

The residence and transition times for each tolerance band were used to quantify the differences between the temperature profiles as a function of velocity (see Table 3 ). In the ideal case, the transition times would be zero and the fluid would instantaneously reach equilibrium within each zone. At linear velocities above $10 \mathrm{~mm} \mathrm{~s}^{-1}$, the fluid never entered the tolerance band for the denaturation zone. The total residence time at the set PCR temperatures decreased from $90 \%$ of the total cycle time at $2 \mathrm{~mm} \mathrm{~s}^{-1}(10 \%$ transition time) to $67 \%$ of the cycle time at $20 \mathrm{~mm} \mathrm{~s}^{-1}$ (33\% transition time). The duration of the extension zone masked the change during the first two steps in the PCR cycle at these flow velocities; at velocities above $10 \mathrm{~mm} \mathrm{~s}^{-1}$ the fluid had zero residence time in the denaturation zone, so the majority of the time was accounted for by residence in the extension zone. In the denaturation zone, heat was not added at a high enough rate to attain equilibrium and it could not be removed quickly enough by natural convection during renaturation. The changes in residence and transition times were relatively stable for velocities below $6 \mathrm{~mm} \mathrm{~s}^{-1}$, but developed a significant gradient above $6 \mathrm{~mm} \mathrm{~s}^{-1}$.

The finite element simulations show that under nominal heating and cooling conditions, the CFPCR device, when operated below a velocity of $6 \mathrm{~mm} \mathrm{~s}^{-1}$, will produce the necessary setpoint temperatures for the PCR, but the residence time within any zone is reduced when the linear velocity is increased. The denaturation zone residence time reduced to zero for linear velocities $>10 \mathrm{~mm} \mathrm{~s}^{-1}$ and the nominal renaturation temperature was reached for only a short period of time. The critical design points to reduce these limitations are the addition of heat in the denaturation zone and the removal of heat in the transition between denaturation and renaturation. Heat addition can be addressed relatively easily by increasing the current available to the heater. Heat removal at a higher rate is a more challenging problem and requires the use of active cooling via thermoelectric coolers, heat exchangers, or fans to obtain the desired temperature profiles at these higher velocities. These solutions would potentially compromise the compactness of the device.

\section{Experimental methods \\ CFPCR device and apparatus}

The CFPCR device designed and fabricated in Liu et al., ${ }^{34}$ Bejat et al., ${ }^{35}$ and Mitchell et al. ${ }^{36}$ was used for these experiments. A mold insert for hot embossing was produced using the LIGA process. $^{43-45}$

The mold insert was used to hot emboss several microfluidic channels in polycarbonate substrates (Goodfellow, UK) using a PHI (City of Industry, CA) press equipped with a vacuum chamber. Inspection of SEM micrographs indicated that the 


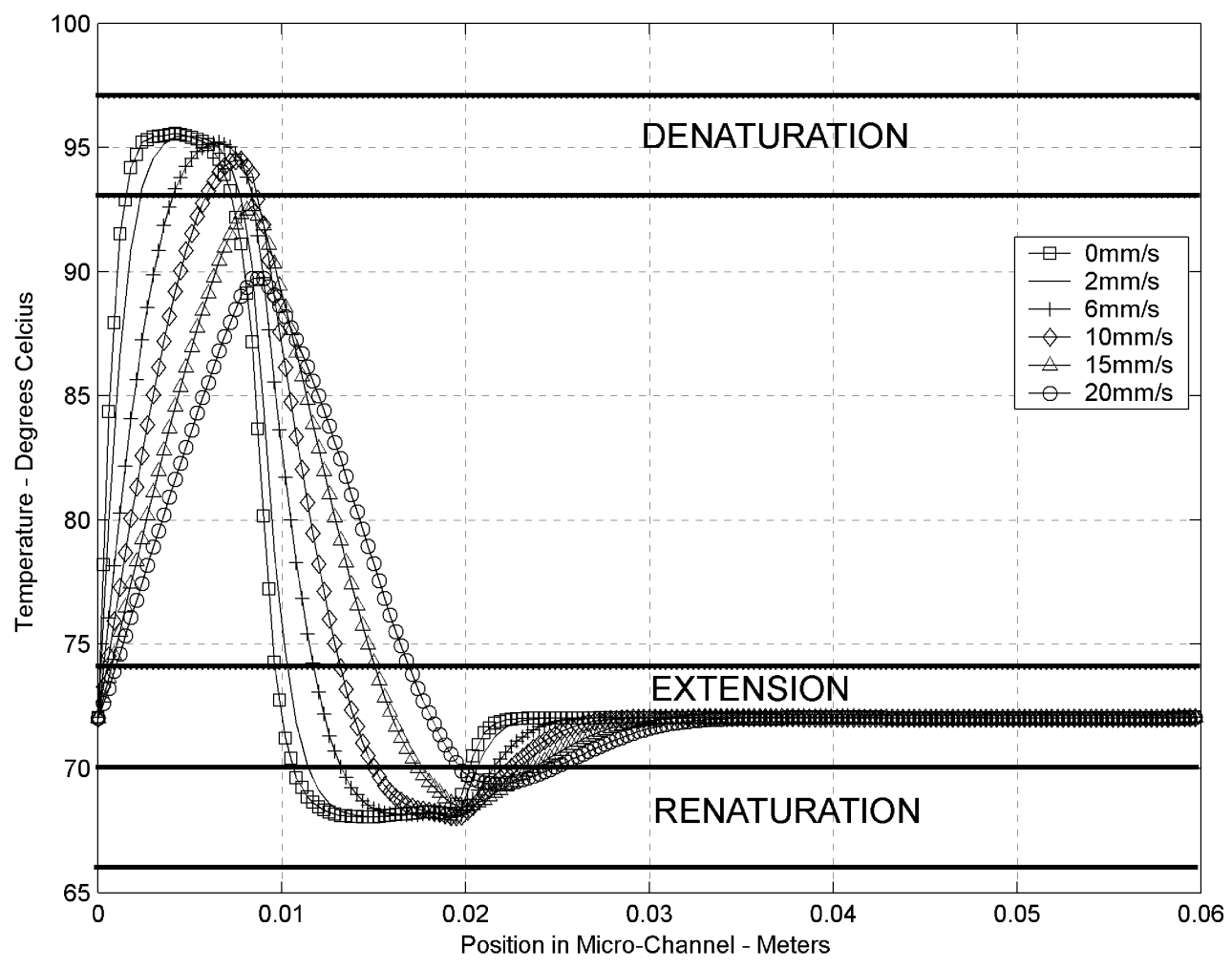

Fig. 2 Simulated temperature distribution along the micro-channel for different fluid velocities. Tolerance bands of $\pm 2{ }^{\circ} \mathrm{C}$ are shown about the setpoint temperatures for denaturation, renaturation, and extension. As the velocity increases above $10 \mathrm{~mm} \mathrm{~s}^{-1}$ the fluid temperature does not reach the nominal denaturation $\left(95^{\circ} \mathrm{C}\right)$ and renaturation $\left(68{ }^{\circ} \mathrm{C}\right)$ temperatures and the time at the extension temperature decreases by more than $20 \%$.

Table 3 Residence and transition times as a function of the fluid velocity

\begin{tabular}{|c|c|c|c|c|c|c|c|c|c|}
\hline $\begin{array}{l}\text { Mean velocity } \\
/ \mathrm{mm} \mathrm{s}^{-1}\end{array}$ & $\begin{array}{l}\text { Max velocity } \\
/ \mathrm{mm} \mathrm{s}^{-1}\end{array}$ & $\begin{array}{l}72-95{ }^{\circ} \mathrm{C} \\
/ \mathrm{s}\end{array}$ & $\begin{array}{l}95^{\circ} \mathrm{C} \\
/ \mathrm{s}\end{array}$ & $\begin{array}{l}95-68{ }^{\circ} \mathrm{C} \\
/ \mathrm{s}\end{array}$ & $\begin{array}{l}68{ }^{\circ} \mathrm{C} \\
/ \mathrm{s}\end{array}$ & $\begin{array}{l}68-72{ }^{\circ} \mathrm{C} \\
/ \mathrm{s}\end{array}$ & $\begin{array}{l}72^{\circ} \mathrm{C} \\
/ \mathrm{s}\end{array}$ & $\begin{array}{l}\text { Single cycle time } \\
/ \mathrm{s}\end{array}$ & $\begin{array}{l}20 \text { cycle time } \\
/ \mathrm{s}\end{array}$ \\
\hline 2 & 2.7 & 1.154 & 2.73 & 1.849 & 4.578 & 0 & 19.689 & 30 & 890 \\
\hline 3 & 5.6 & 0.924 & 1.721 & 1.325 & 2.973 & 0 & 13.057 & 20 & 593 \\
\hline 4 & 7.5 & 0.801 & 1.221 & 1.07 & 2.168 & 0 & 9.74 & 15 & 445 \\
\hline 5 & 9.4 & 0.727 & 0.927 & 0.912 & 1.69 & 0 & 7.744 & 12 & 345 \\
\hline 6 & 11.2 & 0.677 & 0.726 & 0.805 & 1.374 & 0 & 6.418 & 10 & 296 \\
\hline 10 & 18.7 & 0.584 & 0.283 & 0.636 & 0.741 & 0 & 3.756 & 6 & 178 \\
\hline 15 & 28.1 & 0 & 0 & 1.161 & 0.416 & 0 & 2.423 & 4 & 118 \\
\hline 20 & 37.4 & 0 & 0 & 0.985 & 0.251 & 0 & 1.764 & 3 & 89 \\
\hline
\end{tabular}

sidewalls of the embossed channels were straight and smooth and contained the insert-defined channel width and height indicating minimal replication errors.

A syringe pump (Harvard 22, Harvard Apparatus, Holliston, MA) was used to drive the PCR mixture through the spiral micro-channel. A glass syringe (Hamilton, Reno, NV) with a syringe-to-capillary adapter was used to make the connection between the pump and the microfluidic device. Temperatures were maintained during operation using electrical resistance heaters (KHLV-101/10, Omega Engineering, Inc., Stamford, CT) under closed-loop PID control (CN77R340, Omega Engineering, Inc., Stamford, CT). Temperature feedback was through Type K thermocouples (5TC-TT-K-36-36, Omega Engineering, Inc., Stamford, CT) mounted between the cover plates and heaters.

\section{PCR cocktail}

Either a 500 bp or 997 bp DNA fragment was individually amplified with a common forward primer (5'-GATGAGTTCGTGTCCGTACAACTGG-3') and different sequences of the reverse primers (5'-GGTTATCGAAATCAGCCACAGCGCC$3^{\prime}$ for the $500 \mathrm{bp}$ fragment; 5'-GTACCTTTGTCTCACGGGCAACCTG-3' for the 997 bp fragment). The forward primer was labeled with IRD800 (Li-COR, Lincoln, NE) at its $5^{\prime}$-end for post-PCR fluorescence detection. The PCR cocktail consisted of $10 \mathrm{mM}$ Tris- $\mathrm{HCl}(\mathrm{pH} 8.3), 2 \times$ BSA $\left(0.5 \mu \mathrm{g} \mu \mathrm{L}^{-1}\right)$, $50 \mathrm{mM} \mathrm{KCl}, 1.5 \mathrm{mM} \mathrm{MgCl}_{2}, 200 \mu \mathrm{M}$ of each dNTP, the primer pair $(0.2 \mu \mathrm{M}$ each $), \quad 0.1-10 \quad \mathrm{ng} \mu \mathrm{L}^{-1}$ bacteriophage

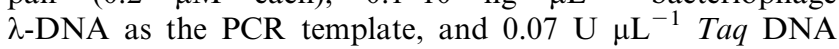
polymerase. The template was thoroughly denatured by heating to $95{ }^{\circ} \mathrm{C}$ for 2 min prior to addition of the PCR cocktail.

\section{Methods}

Before pumping the PCR cocktail through the micro-channels, the channel was washed sequentially by pumping distilled water followed by $1 \times$ PCR buffer containing $2 \times$ BSA. The PCR mixture containing the template was then pumped through the chip at the appropriate linear velocity with the PCR products collected into a microfuge tube from the 
capillary outlet of the chip. Nominally, the temperature of the denaturation zone was set at $95^{\circ} \mathrm{C}$, and the temperature of the extension zone was set to $72{ }^{\circ} \mathrm{C}$. Active heating was not applied to the renaturation zone. The collected samples were analyzed using a 5.5\% crosslinked polyacrylamide gel. Fluorescence from the product was imaged by the Global $\mathrm{IR}^{2} \mathrm{DNA}$ analysis system (Li-COR, Lincoln, NE) and the resultant band integrated over each separation lane with ImageQuant software (Amersham Biosciences, Piscataway, NJ). As a reference, the same PCR mixture used for the CFPCR device was run on a commercial thermal cycler (Techne, Burlington, NJ) using the same number of cycles (20).

\section{Experimental results and discussion}

The PCR products generated from the micro-CFPCR device at flow velocities of 1,2 , and $3 \mathrm{~mm} \mathrm{~s}^{-1}$ are shown in Fig. 3. The integrated fluorescence intensities from the PCR product gel bands obtained from the CFPCR were normalized with respect to the integrated fluorescence intensity obtained from the reference (see Fig. 3b). The results demonstrate that about $25 \%, 20 \%$, and $10 \%$ of the reference PCR product yield was obtained for flow velocities of 1,2 , and $3 \mathrm{~mm} \mathrm{~s}^{-1}$, respectively, using the CFPCR device. The chip produced a total of 20 thermal cycles with the loops possessing a mean time ratio between 1:1:3 and 1:1:4 for each step of the PCR process (denaturation : renaturation : extension), with the exact ratio depending on the location of each loop (1:1:3 in the outer most loop). The 20 cycles were completed in $25.9,12.9$, and $8.6 \mathrm{~min}$ with cycle rates of $77.9,38.9$, and $25.9 \mathrm{~s} \mathrm{cycle}^{-1}$, respectively, for the three flow velocities used here, while approximately $50 \mathrm{~min}$ was required for the reference cycler to perform 20 thermal cycles $(30 \mathrm{~s}$ denaturation, $30 \mathrm{~s}$ renaturation, and $40 \mathrm{~s}$ extension). The product yield for the CFPCR device was about $25 \%$ that obtained using the conventional thermal cycler at the lowest linear velocity used $\left(1 \mathrm{~mm} \mathrm{~s}^{-1}\right)$ that roughly provides $14 \mathrm{~s}, 14 \mathrm{~s}$, and $49 \mathrm{~s}$ for the denaturing, renaturing, and extension, respectively. The lower product yield was due to partial deactivation of the Taq polymerase by adsorption to the high surface-to-volume ratio PCR micro-channel (PC) and/or insufficient residence time in each temperature zone.

In order to simplify the device architecture and allow sufficient time for extension at the elevated linear velocities, a two temperature step PCR cycle was investigated, where the hybridization step was combined with the extension step. To determine the optimal temperature for renaturation and extension, the combined renaturation/extension step temperature was changed by increments of $2{ }^{\circ} \mathrm{C}$, in a range of $68-76^{\circ} \mathrm{C}$ with a constant period of $40 \mathrm{~s}$, and the product yield examined. The reference product was obtained using the commercial cycler with the following thermal cycling program: predenaturing at $95{ }^{\circ} \mathrm{C}$ for $2 \mathrm{~min}$, followed by 20 cycles with denaturing at $95{ }^{\circ} \mathrm{C}$ for $30 \mathrm{~s}$, renaturing at $66^{\circ} \mathrm{C}$ for $30 \mathrm{~s}$, and extension at $72{ }^{\circ} \mathrm{C}$ for $40 \mathrm{~s}$. The product yield decreased significantly compared to the conventional three temperature step process when the renaturation/extension temperature exceeded $\sim 74{ }^{\circ} \mathrm{C}$, but little difference in yield resulted if the two step cycling used a temperature below $70{ }^{\circ} \mathrm{C}$. The calculated $T_{\mathrm{m}}$ for the duplexes formed between the forward and reverse (500 and $997 \mathrm{bp}$ fragments) primers and template was $60.6{ }^{\circ} \mathrm{C}, 63.7{ }^{\circ} \mathrm{C}$ and $62.9{ }^{\circ} \mathrm{C}$, respectively, at the concentrations used for these experiments. Based on the observed $T_{\mathrm{m}}$ for these primer/target duplexes, at least a $50 \%$ reduction in product yield based on the $T_{\mathrm{m}}$ and the temperature used for renaturation/extension would be expected. However, the higher temperature used for primer renaturation minimized PCR false priming events yielding better specificity in the amplification process and more efficient (a)

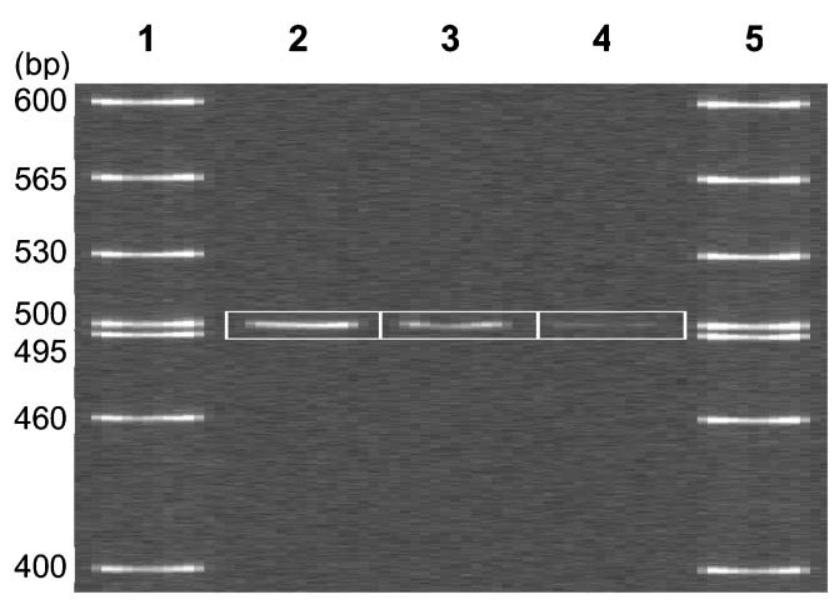

(b)

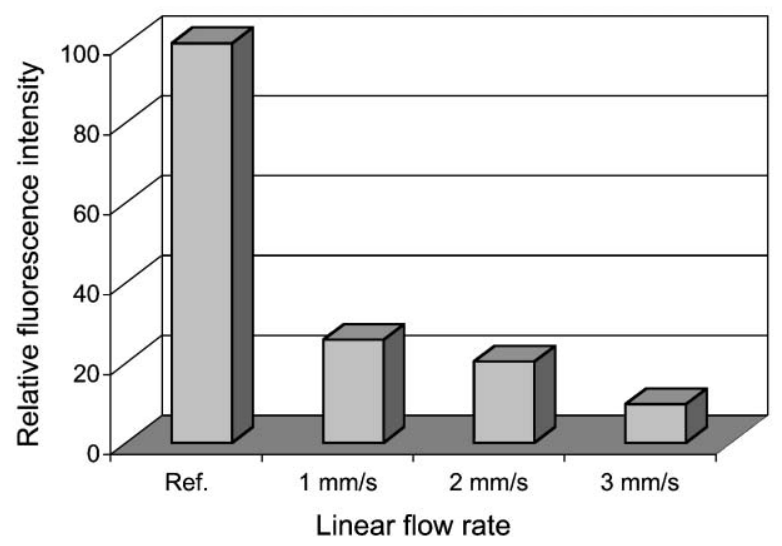

Fig. 3 Effect of the flow velocity on the product yield. (a) Fluorescence images of the PCR products in the $5.5 \%$ polyacrylamide gel matrix. Lanes 1 and 5: DNA size markers. Lanes 2-4: CFPCR products at various flow velocities, 1,2 , and $3 \mathrm{~mm} \mathrm{~s}^{-1}$, respectively Each PCR product was diluted 10 fold in TE buffer, then mixed with loading dye. The solution was denatured at $95^{\circ} \mathrm{C}$ for $2 \mathrm{~min}$, then cooled on ice before gel loading. (b) Fluorescence was integrated over the indicated area in (a) with the image integration software. Values were normalized to the fluorescence of the product from the reference thermal cycler $(100 \%)$. The reference product was obtained using the commercial cycler with the following thermal cycling program: predenaturing at $95^{\circ} \mathrm{C}$ for $2 \mathrm{~min}$, followed by 20 cycles with denaturing at $95{ }^{\circ} \mathrm{C}$ for $30 \mathrm{~s}$, renaturing at $66^{\circ} \mathrm{C}$ for $30 \mathrm{~s}$, and extension at $72{ }^{\circ} \mathrm{C}$ for $40 \mathrm{~s}$.

use of the available primers. The results indicated that a temperature of slightly below $70{ }^{\circ} \mathrm{C}$ provided a sufficient number of primer/template duplexes to produce PCR yields comparable to typical three-step PCR formats. The finite element simulation results (see Fig. 2) predicted that the microCFPCR would be able to drop the fluid temperature below $70{ }^{\circ} \mathrm{C}$ for sufficient periods of time for fluid velocities up to $20 \mathrm{~mm} \mathrm{~s}^{-1}$ to permit adequate renaturation events for perfectly matched duplexes.

For some applications, it may be important to obtain a detectable amount of PCR product quickly from a low copy number sample. Therefore, a study was carried out to establish the minimum copy number of template that could be detected when amplified through 20 thermal cycles using the CFPCR at a linear velocity of $10 \mathrm{~mm} \mathrm{~s}^{-1}\left(7.8 \mathrm{~s} \mathrm{cycle}^{-1}\right.$ and $2.6 \mathrm{~min}$ for completing the reaction). The results of these studies are depicted in Fig. 4a. The fluorescence bands in Fig. 4a were integrated over each separation lane and a plot of integrated intensity versus copy number is shown in Fig. 4b. The 
(a)

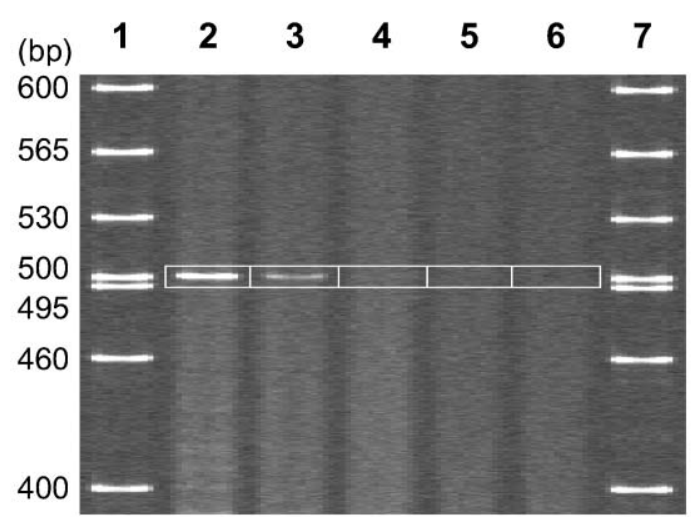

(b)

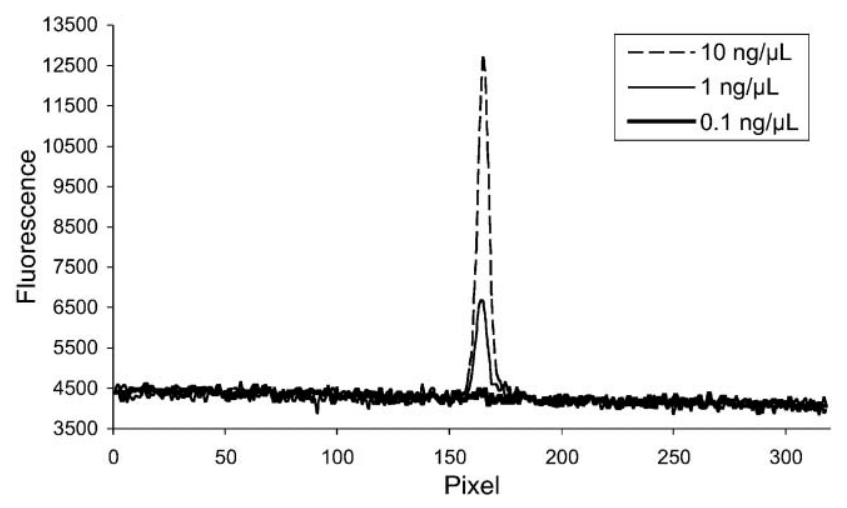

Fig. 4 Fluorescence intensity of the PCR product gel band as a function of the input DNA copy number. A linear velocity of $10 \mathrm{~mm} \mathrm{~s}^{-1}$ was used. Each PCR solution was mixed with loading dye, then denatured at $95{ }^{\circ} \mathrm{C}$ for $2 \mathrm{~min}$, followed by cooling on ice prior to gel loading. (a) Fluorescence images of the PCR products in the $5.5 \%$ polyacrylamide gel matrix. Lanes 1 and 7: DNA size markers. Lanes 2-6: continuous-flow PCR products at various input DNA copy numbers, 10 ,

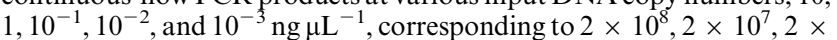
$10^{6}, 2 \times 10^{5}$, and $2 \times 10^{4}$ copies $\mu \mathrm{L}^{-1}$, respectively. (b) Fluorescence intensity integrated over each lane from the top panel with the image integration software used to draw the lines of pixel $v s$. total fluorescence intensity.

minimum template concentration that could be detected at $10 \mathrm{~mm} \mathrm{~s}^{-1}$ was $1 \mathrm{ng} \mu \mathrm{L}^{-1}$, which corresponds to approximately $2 \times 10^{7}$ copies. Although no visible product band was apparent for $0.1 \mathrm{ng} \mu \mathrm{L}^{-1}$ template, this does not necessarily mean that no product was generated at those concentrations, but most likely the amount of product produced under these PCR conditions was smaller than the detection limit of the fluorescence scanner associated with this gel apparatus. The PCR products were labeled with a near-IR dye molecule at the forward primer's 5 '-end, which typically improves detection sensitivity by $20 \times$ compared to conventional DNA staining with ethidium bromide. ${ }^{46}$ Random incorporation of plural numbers of fluorescent dye molecules into the PCR product during the reaction may provide improved sensitivity compared to the single 5 '-end labeling employed here when fast PCR is required. ${ }^{47-49}$

PCR runs were next performed with a template concentration of $10 \mathrm{ng} \mu \mathrm{L}^{-1}$ to determine an upper bound on the linear velocity that could be used using micro-CFPCR for the generation of either a 500 or 997 bp fragment. Fig. 5a shows PCR results for the $500 \mathrm{bp}$ fragment at linear velocities of 10 , 15 , and $20 \mathrm{~mm} \mathrm{~s}^{-1}$. The product band was detectable up to a flow velocity of $\sim 15 \mathrm{~mm} \mathrm{~s}^{-1}$, which allowed completion of 20 PCR cycles in only $1.7 \mathrm{~min}$ with a per cycle time of $5.2 \mathrm{~s}$. For (a)

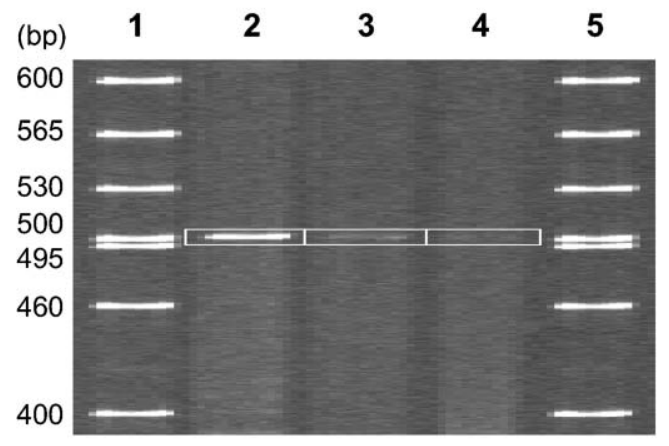

(b)

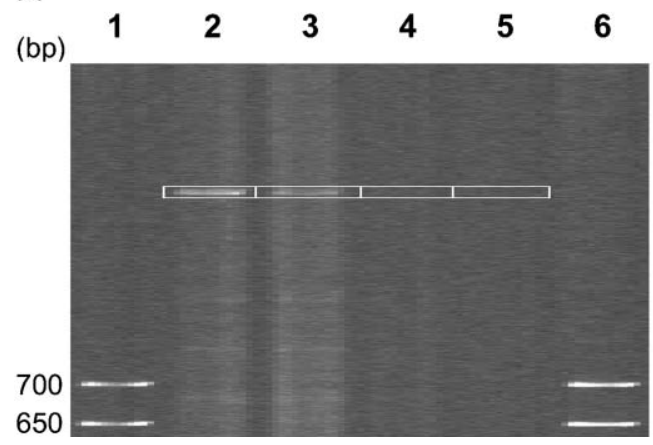

Fig. 5 (a) Linear velocity effects for the generation of a 500 bp PCR fragment. The identical concentration of input DNA molecules (10 ng $\mu \mathrm{L}^{-1}$ ) was used for all CFPCR results. Each solution was mixed with loading dye, then denatured at $95^{\circ} \mathrm{C}$ for $2 \mathrm{~min}$, followed by cooling on ice before gel loading. Lanes 1 and 5: DNA size markers. Lanes 2-4: CFPCR products at velocities of 10,15 , and $20 \mathrm{~mm} \mathrm{~s}^{-1}$, corresponding to cycle rates of $7.8,5.2$, and $3.9 \mathrm{~s} \mathrm{cycle}^{-1}$, respectively. (b) Linear velocity effects on the generation of a 997 bp PCR fragment. The PCR reactions were carried out using the same conditions as in Fig. 5a except for the sequence of the reverse primer. Lanes 1 and 6: DNA size markers. Lanes 2-5: continuous-flow PCR products at linear velocities of $6,8,10$, and $15 \mathrm{~mm} \mathrm{~s}^{-1}$, corresponding to cycle rates of $12.9,9.7,7.8$, and $5.2 \mathrm{~s} \mathrm{cycle}^{-1}$, respectively.

the $997 \mathrm{bp}$ fragment, the maximum linear velocity that could be used to produce a detectable product was $\sim 8 \mathrm{~mm} \mathrm{~s}^{-1}$, giving a total reaction time of $3.2 \mathrm{~min}$ with the cycle time equal to $9.7 \mathrm{~s}$ (see Fig. 5b). It is difficult to conclude from this data whether those cycle times (5.2 and $9.7 \mathrm{~s}$ for the 500 and $997 \mathrm{bp}$ fragments, respectively) represent the fundamental limit on PCR (the residence time in the extension zone below the kinetic rate of the polymerase enzyme) or due to the limitation of generating detectable amounts of product for the fluorescence gel reader. However, when the linear velocity is increased to reduce amplification time, the required cycle rate to generate product for PCR is primarily determined by the polymerase extension time when thermal equilibrium is rapid as is the case for CFPCR. When differences in product yield are seen for two PCR fragments that differ only in size, the observed results can only be explained by the residence time in the extension zone approaching the kinetic limit for the PCR unless the primers differ in renaturing specificity since thermal equilibration effects on product yield are unaffected by product size. In addition, since the denaturation temperatures of the primer sets used for each PCR product were comparable, the denaturation/renaturation kinetics cannot be used to explain the product yield differences between these two fragments. As extension times are decreased below the kinetic limit for fully extending the fragment length defined by the forward and reverse primer pair, a failed PCR reaction will result. Therefore, it is clear that under favorable thermal conditions, the fundamental limit on PCR time is highly dependent on the length of the product required. 


\section{Conclusions}

A continuous flow PCR (CFPCR) device was microfabricated from polycarbonate and its performance as a function of reaction speed was demonstrated. The ease of fabrication and the low cost associated with the device should make it particularly attractive for clinical diagnostic applications, where rapid PCR results are required. Finite element analysis (FEA) was used to help understand the heat transfer to the fluid mixture along a single channel and how the temperature distribution varied among different channel radii on the 20 cycle spiral CFPCR device. The transition and residence times of the fluid in each temperature zone were estimated to determine the effect of increasing flow velocity and changing heat transfer characteristics on the product yield. While the device was shown to produce product yields that were approximately $25 \%$ lower than that of a conventional block thermal cycler when operated with similar cycling times, the micro-CFPCR device could produce products at a much faster rate compared to conventional thermal cyclers due to better thermal management. The CFPCR device could produce $500 \mathrm{bp}$ fragments from $\lambda$-DNA in as little as $1.7 \mathrm{~min}\left(5.2 \mathrm{scycle}^{-1}\right)$ and a $997 \mathrm{bp}$ fragment in $3.2 \mathrm{~min}\left(9.7 \mathrm{~s} \mathrm{cycle}^{-1}\right)$ with the limit on PCR time set by enzyme kinetics ( $T a q$ polymerase).

\section{Acknowledgements}

This work was supported by a Bioengineering Research Partnership (NIH R24-EB002115) through the National Human Genome Research Institute (NHGRI), the National Cancer Institute (NCI), and the National Institute of Bioimaging and Bioengineering (NIBIB) of the National Institutes of Health $(\mathrm{NIH})$

\section{References}

1 K. B. Mullis and F. A. Faloona, Methods Enzymol., 1987, 155, 335-350.

2 S. I. Makino, H. I. Cheun, M. Watarai, I. Uchilda and K. Takeshi, Lett. Appl. Microbiol., 2001, 33, 237-240.

3 S. I. Makino and H. I. Cheun, J. Microbiol. Methods, 2003, 53, 141-147.

4 S. Ito, H. Nakanishi, T. Hirai, T. Kato, Y. Kodera, Z. Feng, Y. Kasai, K. Ito, S. Akiyama, A. Nakao and M. Tatematsu, Cancer Lett., 2002, 183, 195-203.

5 A. K. Zimmermann, P. Simon, J. Seeburger, J. Hoffmann, G. Ziemer, H. Aebert and H. P. J. Wendel, Cell. Mol. Med., 2003, 7, 146-156.

6 C. T. Wittwer, G. C. Fillmore and D. J. Garling, Anal. Biochem., 1990, 186, 328-331.

7 C. T. Wittwer and D. J. Garling, BioTechniques, 1991, 10, 76-78, 80-83.

8 M. A. Innis, K. B. Myambo, D. H. Gelfand and M. A. D. Brow, Proc. Natl. Acad. Sci. USA, 1988, 85, 9436-9440.

9 R. Rasmusessen, Rapidcyclist, 1992, 1, 77-83.

10 H. Swerdlow, B. J. Jones and C. T. Wittwer, Anal. Chem., 1997, 69, $848-855$.

11 R. P. Oda, M. A. Strausbauch, A. F. R. Huhmer, N. Borson S. R. Jurrens, J. Craighead, P. J. Wettstein, B. Eckloff, B. Kline and J. P. Landers, Anal. Chem., 1998, 70, 4361-4368.

12 N. A. Friedman and D. R. Meldrum, Anal. Chem., 1998, 70, $2997-$ 3002 .

13 P. Wilding, M. A. Shoffner and L. J. Kricka, Clin. Chem., 1994, 40, 1815-1818.

14 M. A. Shoffner, J. Cheng, G. E. Hvichia, L. J. Kricka and P. Wilding, Nucl. Acids Res., 1996, 24, 375-379.

15 B. C. Giordano, J. Ferrance, S. Swedberg, A. F. R. Huhmer and J. P. Landers, Anal. Biochem., 2001, 291, 124-132.

16 A. T. Woolley, D. Hadley, P. Landre, A. J. deMello, R. A. Mathies and M. A. Northrup, Anal. Chem., 1996, 68, 4081-4086.

17 E. T. Lagally, I. Medintz and R. A. Mathies, Anal. Chem., 2001, 73, 565-570.
18 L. C. Waters, S. C. Jacobson, N. Kroutchinina, J. Khandurina, R. S. Foote and J. M. Ramsey, Anal. Chem., 1998, 70, 5172-5176.

19 J. Khandurina, T. E. McKnight, S. C. Jacobson, L. C. Waters, R. S. Foote and J. M. Ramsey, Anal. Chem., 2000, 72, 2995-3000.

20 C. G. Koh, W. Tan, M. Zhao, A. J. Ricco and Z. H. Fan, Anal. Chem., 2003, 75, 4591-4598.

21 M. A. Burns, C. H. Mastrangelo, T. S. Sammarco, F. P. Man, J. R. Webster, B. N. Johnsons, B. Foerster, D. Jones, Y. Fields, A. R. Kaiser and D. T. Burke, Proc. Natl. Acad. Sci. USA, 1996, 93 5556-5561.

22 Y. Liu, C. B. Rauch, R. L. Stevens, R. Lenigk, J. Yang, D. B. Rhine and P. Grodzinski, Anal. Chem., 2002, 74, 3063-3070.

23 D. Trau, T. M. H. Lee, A. I. K. Lao, R. Lenigk, I-M. Hsing, N. Y. Ip, M. C. Carles and N. J. Sucher, Anal. Chem., 2002, 74, 3168-3173.

24 H. Nakano, K. Matsuda, M. Yohda, T. Nagamune, I. Endo and T. Yamane, Biosci., Biotechnol. Biochem., 1994, 58, 349-352.

25 J. Liu, M. Enzelberger and S. Quake, Electrophoresis, 2002, 23, 1531-1536.

26 M. U. Kopp, A. J. Mello and A. Manz, Science, 1998, 280, 1046 1048.

27 M. Curcio and J. Roeraade, Anal. Chem., 2003, 75, 1-7.

28 P. J. Obeid, T. K. Christopoulos, H. J. Crabtree and C. J. Backhouse, Anal. Chem., 2003, 75, 288-295.

29 P. J. Obeid and T. K. Christopoulos, Anal. Chim. Acta, 2003, 494 $1-9$.

30 J. Chiou, P. Matsudaira, A. Sonin and D. Ehrlich, Anal. Chem., 2001, 73, 2018-2021.

31 N. Park, S. Kim and J. H. Hahn, Anal. Chem., 2003, 75, 6029-6033.

32 Y. D. Bejat, Micro-Chip Design, Numerical Simulation and MicroPIV Diagnostics for DNA Assays, Dept. of Mechanical Engineering, Masters Thesis, Louisiana State University, Baton Rouge, LA, 2001.

33 M. Mitchell, Design and Microfabrication of a Molded Polycarbonate Continuous Flow Polymerase Chain Reaction Device, Dept. of Mechanical Engineering, LSU Masters Thesis, 2002.

34 X. Liu, M. W. Mitchell, Y. Bejat, D. E. Nikitopoulos, S. A. Soper and M. C. Murphy, J. Microlith. Microfab. Microsys., submitted.

35 Y. Bejat, M. W. Mitchell, D. E. Nikitopoulos, X. Liu, S. A. Soper and M. C. Murphy, J. Microlith. Microfab. Microsys., submitted.

36 M. Mitchell, X. Liu, W. Bejat Y., S. M. Ford, D. E. Nikitopoulos, S. A. Soper and M. C. Murphy, in MicroFluidics, BioMEMS, and Medical Microsystems, ed. H. Becker and P. Wolas, Society of Photo-optical Instrumentation Engineers (SPIE) 2002, vol. 4982, pp. 83-98.

37 Y. Lin, C. Yang and M. Huang, Sens. Actuators B, 2000, 71, $127-$ 133.

38 C. Chou, R. Changrani, P. Roberts, D. Sadler, J. Burdon, F. Zenhausern, S. Lin, A. Mulholland, N. Swami and R. Terbrueggen, Microelectron. Eng., 2002, 61-62, 921-925.

$39 \mathrm{~S}$. Li and S. Chen, in Micro-Electro-Mechanical Systems (MEMS) 2002, Fluidics, BioMEMS, and Medical Microsystems, ed. H. Becker and P. Wolas, Proceedings of ASME Int'l. Mechanical Engineering Congress \& Exposition (IMECE 20002), November 17-22, New Orleans, LA, 2002.

40 K. Sun, A. Yamaguchi, Y. Ishida, S. Matsuo and H. Misawa, Sens. Actuators B, 2002, 84, 283-289.

41 Q. Zhang, W. Wang, H. Zhang and Y. Wang, Sens. Actuators B, 2002, 82, 75-81

42 H. L. Dryden, F. D. Murnaghan and H. Bateman, Hydrodynamics, Bull. No. 84, pp. 197-201. Comm. Hydrodyn., Div. Phy. Sci., Res. Counc., Washington, DC., 1932: reprinted by Dover, New York, 1956.

43 M. Madou, Fundamentals of Microfabrication, CRC Press, Inc., Boca Raton, FL, USA, 1997.

44 S. Qi, S. M. Ford, X. Liu, J. Barrows, G. Thomas, K. Kelly, A. McCandless, K. Lian, J. Goettert and S. A. Soper, Lab Chip, 2002, 2, 88-95.

45 Y. M. Desta, G. Aigeldinger, K. J. Zanca, P. Coane, J. Gottert and M. C. Murphy, in Materials and Devices Characterization in Micromachining III, ed. Y. Vladimirsky and P. J. Coane, Society of Photo-optical Instrumentation Engineers (SPIE), 2000, vol. 4175, pp. $122-130$

46 P. K. E. Magnusson, E. Wilander and U. Gyllensten, BioTechniques, 1996, 21, 844-847.

47 Z. Zhu and A. S. Waggoner, Cytometry, 1997, 28, 206-211.

48 Z. Foldes-Papp, B. Angerer, W. Ankenbauer and R. Rigler, J. Biotechnol., 2001, 86, 237-253.

49 W. Zheng and S. Chen, Proc. SPIE Int. Soc. Opt. Eng., 2001, 4560, 256-262. 